\title{
Financial integration and national autonomy: China and India*
}

\author{
Sunanda Sen \\ Jamia Millia Central University, New Delhi, India
}

The narrative as well as the analysis of deregulated finance in the global economy remain incomplete unless one relates to the surges as well as volatility in capital flows which are experienced by the emerging economies. An analysis as above needs to consider the implications of capital flows in those economies, especially in terms of the 'impossibility' of adopting monetary policies which benefit growth in the national economy. There is also a need to recognise the role of uncertainty and the related changes in market expectations in the (precautionary) accumulations of the large official reserves as are held by these countries. The consequences are found to affect the fabric of growth and distribution in these economies. Recent experiences of China and India, with their deregulated financial sectors, bear this out.

Financial integration and free capital mobility, which are supposed to generate growth with stability in terms of the 'efficient markets' hypothesis, have failed, and not only in the advanced economies but also in the high-growth developing economies like India and China. Deregulated finance has led these countries to a state of compliance, where domestic goals of stability and development are sacrificed to make way for the globally sanctioned norms relating to free capital flows.

With the global financial crisis and the spectre of recession haunting most advanced economies, issues as above in the high-growth economies in Asia have drawn much less attention than they deserve. This oversight leaves the analysis incomplete by ignoring the structural changes that result in these developing economies - which are of much relevance to the pattern of financialisation and turbulence in the global economy as a whole.

Keywords: global imbalances, recession, capital flows, emerging economies, efficient markets, capital mobility, monetary policy, impossible trilemma

JEL codes: $E 52, E 58, E 63, E 44, F 65, G 01$

\section{INTRODUCTION}

With global crisis and recession haunting most advanced economies, the related problems that have been experienced by the high-growth economies in Asia, such as China and India, deserve more attention than has been seen so far in the literature. Such an oversight makes the related analysis incomplete, not only by missing an important link in the ongoing network of global trade and finance, but also by ignoring

* Comments received from the two referees of the journal are gratefully acknowledged as helpful inputs, which have improved the quality of the paper. 
the structural changes in the developing region, which have a bearing not only within but also between countries in the global economy.

In the present paper I draw attention to the high growth economies of China and India, known as 'emerging economies' in the literature. The growth momentum in the two which prevailed until recently, and the expansions in the stock of their official reserves which continues even in the face of the global recession, makes them unique among developing countries.

My analysis in the present paper provides an attempt to unfold the policy constraints faced by these countries as a consequence of their financial integration. These constraints particularly include a loss of autonomy in their domestic monetary policy, resulting in what has been described in the literature as an 'impossible trilemma' (also named as an 'impossible trinity' by Thomas Palley (2009)). In terms of the latter, policy measures to maintain the three goals of exchange rate stability, capital account opening and monetary autonomy often turn out to be incompatible. As a result, the outcome can move in a direction which is contrary to the interests of the real economy, for example by depressing further the level of activity in an attempt to contain inflation. The contractions that result within the domestic economy are also likely to spill over to the trade partners, by shrinking the magnitude of import demand from the former. Financial opening also instils added degrees of volatility in multiple markets, which include those for financial assets and commodities, as well as for real estates. As I observe in the following pages, in addition to losing autonomy over national monetary policies, China and India have also faced added degrees of volatility in all three markets mentioned above, which resulted from deregulation in their financial sector.

I initiate my discussion in Section 2 by drawing attention to the accumulation of officially held reserves by China and India, with their respective dual and capital account surpluses in the balance of payments. Section 3 invokes the theoretical premise of the 'impossible trilemma' in the literature, which dwells on the difficulties of continuing with monetary autonomy along with free capital flows and exchange rate management. While pointing out the assumptions behind the static framework underlying the theorem (which is essentially an offshoot of the Mundell-Fleming IS-LM framework for open economies), I draw attention to the relevance of uncertainty and expectations as additional dimensions in the process. Section 4 dwells on the related experiences of China and India, in terms of the trilemma, providing examples of the limits the two countries have been facing (a) in pursuing an autonomous monetary policy to instil growth, and (b) with the instabilities related to the changing expectations in the deregulated financial sector and the open capital account. Section 5 offers a conclusion.

\section{PAYMENTS, IMBALANCES, RISING RESERVES AND THEIR DEPLOYMENT BY CHINA AND INDIA}

China's twin surpluses, between external trade and payments, have led to spectacular accumulations in official reserves. Deployment of the latter in US Treasury Bills has been viewed as evidence of the ongoing imbalance in global payments with its potential instabilities in the global economy. Such an issue also addresses the accumulation of reserves by the Emerging Economies as a whole, with reserves held by China of $\$ 3.34$ trillion by December 2012, by Russia of $\$ 537.6$ billion, Brazil of $\$ 373.1$ billion and India of $\$ 295.6$ billion by September 2011. This contrasts with the much smaller 
stock held by the euro area as a whole of $\$ 909.5$ billion and Japan of $\$ 1.26$ trillion, not to mention the USA and UK at respective levels of $\$ 151.2$ billion and $\$ 134.2$ billion only, all around December 2012 (IMF 2013).

Stocks of official reserves held by the emerging economies are usually invested in assets which are considered relatively safe. US Treasury Bills had a major share in such investments. Data released by the US Treasury indicate that of a total of $\$ 5.75$ trillion US Treasury securities held overseas by March 2013, a major share was held by China at $\$ 1.25$ trillion. The other three countries in the BRIC group (Brazil, Russia and India) had, between them, $\$ 477$ million by the same date (Treasury Direct 2012). It is thus no surprise that China's current account surpluses, the related rise in the official reserves and their investments in US Treasury securities have drawn so much attention in an analysis of global payment imbalances, often held as a potential for further crises in global finance.

From an accounting point of view, current account surpluses and deficits represent imbalances between savings and investment at national levels. Policies advocated to restore balance in external payments often include deflationary strategies for countries with payment surpluses along with a revaluation of their national currencies. Strategies as above were in fact recommended to China by US monetary authorities. By doing this, the US was even viewed as a 'passive' partner, which is adjusting to the 'savings glut' of the East Asian countries (including China), especially as those are drawn to assets denominated in dollars. ${ }^{1}$ One can here refer to the oft-quoted speech by Ben Bernanke in 2005, with its claim that the current account deficits of the US have been a consequence of the 'savings glut' in China and other East Asian countries. Also that these countries have been accumulating international assets as a "cautionary step', on the basis of what they experienced during the Asian crisis of 1997-2008. Apprehending problems in sustaining these current account and savings investment imbalances, Bernanke suggested that China, the surplus nation, and the USA, the deficit one, should respectively have more investment and savings in their domestic economies (Bernanke 2005).

Opinions on the above, however, vary. Thus, as held from a radically different point of view, China should no longer lend to the 'troubled' euro-area nations (Yongding 2011a). Pointing out how China has got trapped in the rigmaroles as well as the uncertainty around the dollar-RMB exchange rate, it is mentioned that in case China ever starts unloading US securities, there could be chaos in the financial market (Yongding 2012). Attention is also drawn to the prevalence of speculation in the Chinese economy despite the recent official clamp-down on the housing/real estate markets and on the underground credit network. Incidentally, investment in real estate has turned out to be a major source of fixed asset investment in China in recent years, generating a bubble which has burst over the last couple of years (Yongding 2011b). It has also been pointed out that the large US current account deficits have been largely due to policies within the country. As a remedial measure (Bottelier 2011), the US then needs to rebalance its own economy both by keeping consumption growth below GDP growth and strengthening international competition (Bottelier 2009).

Concerns relating to the exchange rate of the RMB, however, have continued, holding the inflexible exchange rate policy of China and other emerging market economies as a major factor which is responsible for the continuing global current account imbalances (Subramonian 2010).

1. For a position along these lines in the US, see Dunaway (2009). 
To sum up, while there are divergent positions regarding the twin surpluses in China's external account and the RMB exchange rate, the focus in general has been on their possible effects on the stability of the global economy as a whole. The story, however, leaves out the effects at national levels, an aspect I will deal with in the following sections.

External payments imbalances, especially at a bilateral level, have not been as prominent in India as they have been in China-US trade. However, with the capital account nearly convertible and with official reserves often peaking at $\$ 300$ billion, India's monetary policy has similarly been subject to changes which infringe upon national autonomy in terms of the selection of domestic economic policies. I deal with this aspect in Section 3 below.

\section{PAYMENT SURPLUSES AND POLICY OPTIONS: THE IMPOSSIBLE TRILEMMA $^{2}$}

The attention paid to global current account imbalances as a potential source of global financial instability leaves out aspects relating to the limits on policy options which are being faced by some developing countries like China and India. These are the countries with surpluses in the capital accounts of their balance of payments, which is often over and above their current account surplus/deficits. Such countries have experienced net inflows of finance from overseas which have often contributed to their official reserves of foreign currency. While the free inflows of finance as above tend to push up the exchange rate of domestic currency in the foreign exchange market, the monetary authorities often try to avoid an appreciation of the currency with direct purchases of foreign currency which adds to official reserves. However, the latter, contributing to what is known as 'high powered money', also adds to money supply which, as believed by the monetary authorities, always causes inflation. Monetary policies are then adjusted to target inflation on a priority basis, even at the cost of expansionary policies for growth.

Situations as above relate to what in the literature is described as an 'impossible trilemma': of having managed exchange rates and free capital flows under capital account convertibility, along with attempts to maintain an autonomous monetary policy. Of the three parameters given above, which define the incompatibility in terms of the 'impossibility' theorem, an option of reversing capital account convertibility by resorting to controls is more or less ruled out today; especially in terms of the logic of open economy macroeconomics embedded in mainstream economics which is followed almost universally. Hence the choice for the policies that remain lies between exchange rate management and national autonomy in monetary policy. It is common knowledge that movements in exchange rate, if left to the market, often clash with other goals, with inflows of capital pushing up the exchange rate of the local currency under a 'Dutch Disease syndrome' which may worsen the trade balance. Thus comes the imperative need to manage the real exchange rate, say within a band, and/or at a crawling peg, or at a fixed real exchange rate which maintains the competitiveness of domestically produced goods. All those leave aside the third goal, which include an autonomous monetary policy.

2. This and the following sections of the paper have used some material from an earlier paper entitled 'Managing Global Finance at Cost of National Economy: China and India', in From Crisis to Growth? The Challenge of Debt and Imbalances, edited by Hansjörg Herr, Torsten Niechoj, Claus Thomasberger, Achim Truger and Till van Treeck, Marburg: Metropolis-Verlag (2012). 
What, then, remain as the accepted parameters of monetary policy in open economies as stated above? To repeat, situations of, say, steady net inflows of capital to those countries with related tendencies for local currency to appreciate and efforts on the part of their monetary authorities to sterilise the influx of foreign exchange by adding onto official reserves may lead to increases in high-powered money $\left(M_{0}\right)$ with its expansionary effects on $M_{3}$, and the latter in turn tend to put pressures on monetary authorities to take further action. Consistent with the monetarist frame of analysis in the Mundell-Fleming model which in effect has its sequel in the 'impossible trilemma' theorem, monetary authorities in such situations put 'inflation targeting' as the prime agenda of their actions. Little attention, however, is paid in the process to the need to harness monetary policy in the interest of growth in the domestic economy, which remains no less important. Moreover, hardly any attention is paid to the related effects in terms of the curbs on social sector spending and public investments which come as a consequence.

With inflation targeting as the primary goal of monetary policy, sale of government bonds has been a convenient tool for achieving monetary stabilisation. This can be observed in the developing countries like China, India and a few other emerging countries, especially with their demonstrated tendencies to accumulate official reserves in key currencies. Increases in reserves are also desired by monetary authorities as precautionary buffer stocks to avoid the unwarranted movements in the exchange rates of their national currencies.

As pointed out by Paul Krugman (1999), the notion of the 'impossible trilemma' is based on the Friedman-Mundell-Fleming IS-LM-BP framework of open economy macroeconomics with policy implications suggesting a flexible exchange rate policy. However, as pointed out, 'the impossible trinity provides an incomplete policy menu that leaves a large part off the table. This omission includes (a) co-ordinated monetary policy across countries; (b) managed exchanged rates between countries; and (c) managed capital flows' (Palley 2009). A 'menu' such as the above, however, leaves much to be fulfilled, especially in the context of the current global financial scenario.

Analysing further the notion of the 'trilemma' in the context of the prevailing pattern in global financial flows and payments imbalances, one can provide one more interpretation of the large reserves held by some emerging economies. As previously pointed out, 'in the absence of a major reform of global financial architecture, emerging markets remain exposed to sudden stops and de-leveraging crises' (Aizenman 2010). These economies thus had an additional urge to hold these reserves as a precautionary measure. As held in this study, these countries are thus faced with what has been described as a 'quadrilemma', which is beyond a 'trilemma', and can be explained by the 'self-insurance' motive on the part of countries faced with additional uncertainties in the global financial market. This study also points out financial deepening (as recorded in the rising M2-GDP ratio) as one more reason on the part of those countries to maintain higher reserves as a measure to tackle possible flights of capital by domestic residents.

The qualification, as above, adds a new dimension to the level of official reserve held as a precaution against 'uncertainty'. The notion also reflects the conceptual weaknesses in the formulation of the 'trilemma' as hinted at above. To spell this out, the trilemma essentially postulates a static framework in terms of the intersecting IS-LM-BP framework. With exchange rates, monetary policy (including interest rates) and the magnitude as well as the composition of capital flows all being subject to movements which are hardly predictable, policy options faced by the concerned countries remain further constrained - an aspect which provides an interpretation of the high reserves maintained 
by those countries. The level of official reserves impacts the policy options of concerned nations in several ways, including the compelling need to target inflation and the related sacrifice of monetary autonomy. From this angle, the prevailing pattern of international financial transactions with the global current account imbalances, while generating the 'excess' reserves held by the emerging market countries, needs to be viewed in the context of the uncertainties and the related compulsions as per force are faced by these countries in the deregulated financial markets.

\section{THE EMERGING MARKETS OF CHINA AND INDIA: POLICY OPTIONS}

Against the above background, one can gain a better understanding of related policy issues in the high-growth economies of China and India. Many of them were in fact related to the developments in the global financial markets. As I pointed out above, contrary to the Bernanke-type notion of the 'savings glut' in the surplus countries, both China and India have in fact been subjected to a path of passive adjustments, and to inflows of speculative (or other) capital from overseas which originate from factors external to their economies. Those passive adjustments include, in the first round, additions to foreign exchange reserves with related impact on money supply as well as prices. This leads to the second-round adjustments in the policy sphere, in terms of options left in formulating domestic monetary policy. The latter include the responses in terms of inflation targeting, with hikes in interest rates, sale of sterilisation bonds, rising reserve ratios and related matters. As pointed out in the context of what I described above as the 'impossible trilemma' theorem, contractionary moves as above are not always conducive to the interests of the domestic economy in terms of growth. However, reserves are also held as precautionary stocks, thus introducing one more constraint or 'quadrillema' for those countries.

In this section I analyse the following four aspects in the policy issues of the two high reserve-high growth emerging economies: China and India. Those concern their (a) imbalance in external payments; (b) exchange rates; and (c) monetary policy options.

\subsection{China}

China's integration into the global markets has been combined with spectacular increases both in its trade surplus and in its net capital inflows, except for the declines at the end of the global financial crisis of 2008-2009 and over 2011-2012 as a result of the eurozone crisis. The rising inflows of capital included both FDI and portfolio, with the latter assuming prominence in more recent years. China's trade surpluses rose from an average of $\$ 196$ billion in 2006 to the spectacular sum of $\$ 315.5$ billion on an average between 2007 and 2008, followed by a modest dip at $\$ 240$ billion on an average between 2009 and 2010 and $\$ 245$ billion in $2011 .^{3}$ This was combined with similar increases in foreign direct investments which rose from $\$ 133$ billion in 2006 to \$177 billion on average during 2007 and 2008, \$219 billion during 2009 and 2010 and $\$ 271$ billion in $2011 .^{4}$

As a result of the above, China has been experiencing twin surpluses, yielding steady inflows of foreign exchange into the market. To avoid possible appreciations

3. http://elibrary-data.imf.org/DataReport.aspx $? c=1449311 \& d=33060 \& \mathrm{e}=161868$.

4. IMF, International Financial Statistics. 
of the domestic currency, the monetary authorities purchased a substantial part of those inflows which in turn contributed to an accumulation of official reserves. Stocks of China's official reserves (excluding gold) shot up from an average of $\$ 339.5$ billion during 2000-2004 to a little under \$1 trillion by September 2006, followed by sums which were $\$ 3$ trillion and above by March $2011 .^{5}$

China, in the earlier years of financial opening (till about 2005), provides a unique example of liberalising its financial sector with close state monitoring, which I have described elsewhere as a situation of 'guided finance' (see Sen 2007). China has gone through a period of rapid financial liberalisation since 2005. By June 2005 foreign investors were allowed to have stakes in the publicly listed firms and buy their tradable A-shares. As reported by domestic media in China (Peng et al. 2007), this was part of an ongoing plan to do away with non-tradable State shares. However, foreign investors taking strategic stakes via their purchases of A-shares were subject to 'lockup' periods, being forbidden from selling them until a specified time. The year 2005 also marked the de-linking of the RMB-to-dollar peg, followed by the appreciation of the nominal RMB rate by 20 per cent between 2005 and 2008. Controls over foreign finance were further loosened by 2007 , as Chinese investors were permitted to buy $\mathrm{H}$-shares in the Hong Kong exchange. Until then, such investments were only permissible on the part of the Qualified Domestic Institutional Investors (QDIIs), which included banks and other domestic financial institutions. This reflects attempts on the part of the monetary authority to offset some of the capital inflows pouring into the country through FDI-led corporate investments and the soaring trade surplus (Green 2003). By July 2007, the inflation rate within the country had soared to 5.7 per cent, largely through high domestic demand (ibid.).

A steady deregulation of China's financial market started in 2005 and continued without much interruption. Rising capital inflows, however, had not impacted the managed exchange rate of the Yuan between 2000 and 2004, when it remained steady at 8.28 RMB per US dollar. Responding to pressures, especially by the US to adjust the currency upwards, the RMB was de-linked from the US dollar by an official announcement which came in July 2005. This led to a moderate revaluation of the currency to RMB 8.11 per dollar. However, the Chinese currency has been appreciating slowly since then, with the most recent figure quoted in the market at RMB 6.24 to a dollar in March 2012. ${ }^{6}$ But the official stance of continuing with monetary interventions in a bid to avoid major appreciations in the national currency seems to have prevailed, especially to combat the simultaneous depreciation in the dollar, a major link currency in currency markets.

However, one could observe a division between officials in China on the exchange rate policy. By 2010, People's Bank of China (PBC) chief Xiao Chuan, was in favour of a gradual relaxation of control over appreciation or otherwise of the yuan rate, which the Commerce Ministry wanted a depreciation to arrest the drop in exports. ${ }^{7}$ Also the RRR (required reserve ratio) was lowered twice during the year, by 100 per cent and a further reduction to 20 per cent. ${ }^{8}$ The $\mathrm{PBC}$ chief also recommended a withdrawal of the currency peg. It is notable that officials in the Bank were in fact also favouring complete convertibility of the capital account which, as held by an official (Jin Xongjia) in 2012, may not be destabilising since capital controls were not as effective at the time (Black 2012).

5. http://www.chinability.com/Reserves.htm.

6. http://www.exchange-rates.org/history/CNY/USD/T.

7. 'Bending not bowing', The Economist, April 8, 2010.

8. http//www/finance.yahoo.com/news/china. 
By this time, with an ongoing slump in the global economy which affected China, the PBC had announced cuts in the benchmark interest rate (for the first time since 2008) by 25 basis points. ${ }^{9,10}$ As Bo Shusong (the Deputy Director of the Financial Research Institute in Beijing) put it, with the yuan stable in the face of other currencies, 'it opened a rare window of opportunity to adopt capital account convertibility'. ${ }^{11}$

In contrast, the Prime Minister, Wen Jibao, had announced in 2010 that China would continue with a stable exchange rate of the RMB (McKinnon 2010). Officials even indicated by 2012 that 'since China's trade surplus had considerably gone down, it shows that RMB is close to an equilibrium level'. ${ }^{12}$ This mood has continued to this day. Pressures from the US on China to appreciate the currency have continued, however, and the US Treasury even came to the point on April 15, 2010 that it is time to decide whether China can be treated as a currency manipulator (Yong 2010).

I analyse below the changes in China's domestic economy, which, by facing a 'trilemma' (or 'quadrilemma') has often faced limits in framing its official policies. I reiterate, at the cost of repetition, what was mentioned in Section 1 as a trilemma under open capital account and managed exchange rate policies. To recap, free entry of overseas capital tends to have its initial impact on the nominal exchange rate of the domestic currency. To avoid an appreciation/depreciation of the domestic currency, monetary authorities often resort to direct purchases/sales of foreign currency which simultaneously generate/contract high-powered money (reserves) with proportionate changes in domestic money stock. Thus officially held exchange reserves, as high-powered money, provide sources of change in the supply of money, an aspect which adds to the pressures on monetary authorities to tighten/ cheapen money supply accordingly. As pointed out by the PBC, 'the root cause of the liquidity problem has not been solved. The RMB equivalent to foreign exchange purchase has become the major source of base money supply while central bank lending to financial institutions accounts for a smaller share. This undermines the independence of monetary policy and makes money supply a more endogenous factor.' ${ }^{13}$ The PBC also points out that 'China is not a small economy. With a population of 1.3 billion, China cannot afford to lose monetary policy independence and subject itself to economic policies of other countries' ${ }^{14}$ To avoid further changes in liquidity in the market, the fiscal authorities often act in unison by selling/buying official bonds in the market (open market operations). Additionally, the monetary authorities change the supply of credit by using tools which include cash-reserve ratios, statutory liquidity ratios, hikes in repo, reverse repo rates and prime lending rates. These are carried out in a bid to control the tendencies that may result from related changes in the availability of liquidity. Such policies, essentially prompted by financial flows from abroad, not only affect the receiving countries in terms of their autonomy in the choice of economic policies, but can also interfere with goals to achieve growth and expansion for their real economies, especially with contractionary effects on supply of credit.

9. Economic Times, June 8, 2012, at www/articles.economictimes.indiatimes.com/2012-06-08.

10. http//www.news.xinhuanet.com/English/china/2012-06june 29/c-13.

11. See footnote 8 .

12. 'Chinese economy: enough appreciation for now', The Economist, March 12, 2012.

13. Hu Xiaolian Exchange Rate Regime Reform and Monetary Policy Effectiveness July 26, 2010 at http://www.pbc.gov.cn/publish/english/956/2010/20100804100116452770088/ 20100804100116452770088_html.

14. As footnote 13 . 


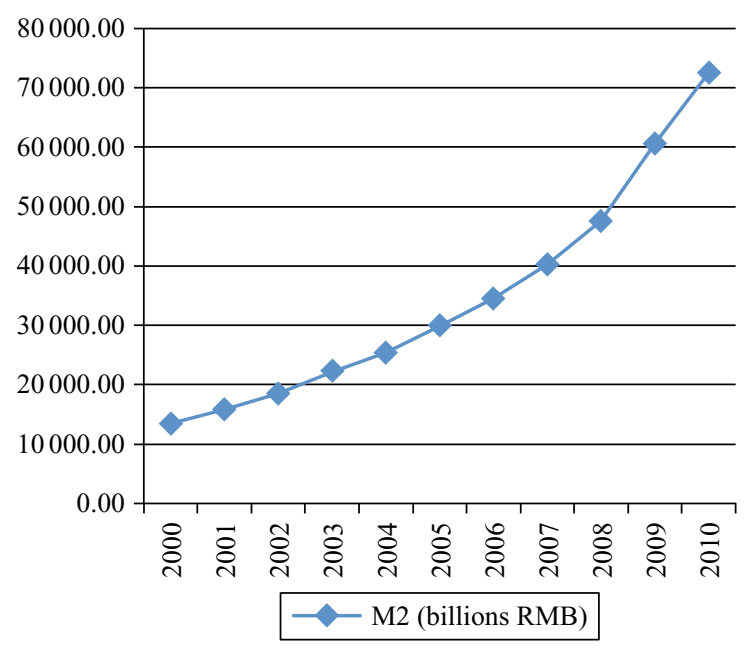

Figure 1 China: changes in M2, 2000-2010

For China, the twin surpluses in its external accounts and exchange rate management have combined to steady expansions in officially held reserves, a large part of which were held as US Treasury Bills. As noted by Yongding (2009), 'in accumulating the large stock of US Treasury Bills, China "faces a triple whammy" by facing capital losses with a possible drop in dollar exchange rates and in prices of the T Bills, plus an inflationary pressure in the domestic economy'. One observes related monetary expansions, especially over the last decade (see Figure 1). The continuing rise in M2 was 14.8 per cent year-on-year (yoy) in September 2012. Earlier, from 2008, the monetary authorities had been using fiscal expansionary policies and injected liquidity, by stopping sales of bonds and by using downward adjustments in the cash reserve ratios maintained by banks (see Figure 2). Such measures led to liquidity expansions in the market and a lowering of inter-bank lending rates with the latter falling even below deposit rates. Recent years, however, have seen a reversal of monetary policy in response to rising prices. By Quarter 2 of 2011, prices were rising by 5.4 per cent (yoy). ${ }^{15}$ To curb liquidity, monetary authorities increased the reserve ratio seven times during the first three quarters of 2011, with the ratio rising by as much as 21.5 per cent by October 21, 2011 (Korner and Ehnts 2011). Measures on the part of monetary authorities to control the recent inflation also included sales of official bonds which depressed the domestic inter-bank lending rate by 0.41 per cent (yoy) in December 2011 when it reached a low of 3.74 per cent. ${ }^{16}$ It can be expected that such actions led liquidity in the market to subside, especially as a consequence of the aggressive sales/purchases of bonds in response to rising cash flows and the related changes in prices. The changing scenario between 2002 and 2010 can be observed from Figure $1 .{ }^{17}$

15. PBC, China Monetary Policy Report Quarter Three, 2011.

16. PBC, China Monetary Policy Report Quarter Four, 2011.

17. The pattern tallies with the data released by the PBC which indicates a drop in CPI between Q1 and Q3 of 2009 by 1.1 per cent (on yoy basis) and a drop in CPI of 1.3 per cent during Quarter 3 of 2009 itself. Loans offered in domestic currency during the quarter expanded 


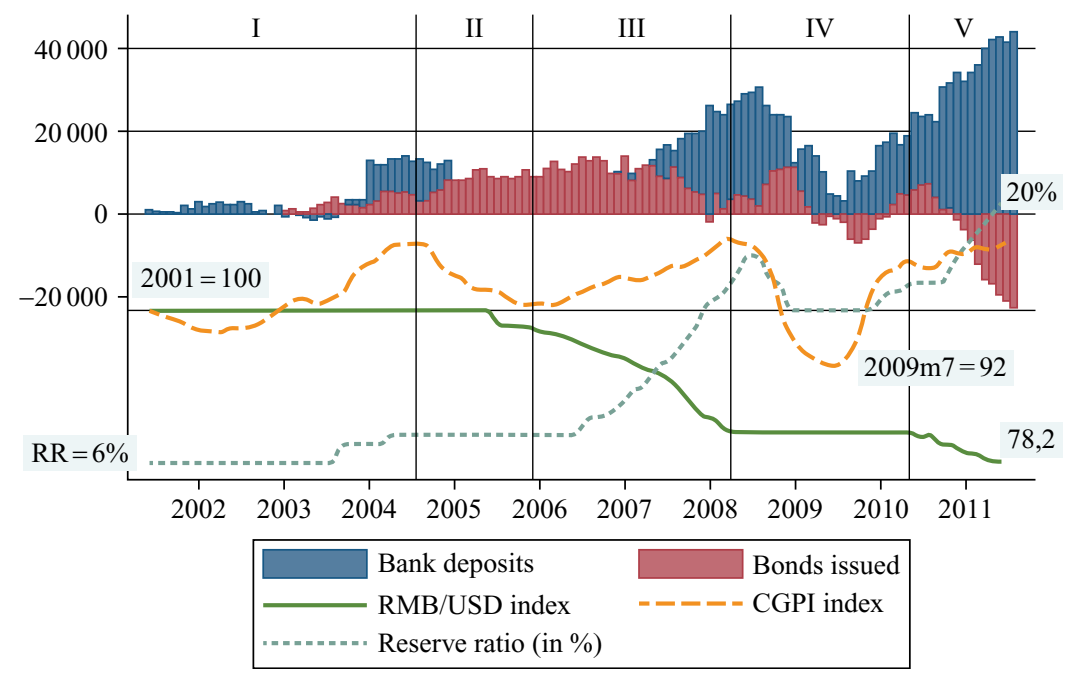

Note: I.h.s. year-on-year changes in stocks in RMB 100m yuan.

Source: Ehnts and Korner (2011), from People's Bank of China.

Figure 2 China: five stages diagram, M2 2001-2011

Inflationary spirals in prices, especially in the property market, led to a real-estate bubble with house prices in coastal areas rising by more than 50 per cent in a year by $2010 .{ }^{18}$ By 2012, the property market showed signs of cooling as the government intervened by providing subsidised low-cost housing worth RMB 7 million. It is, however, noteworthy that investment in real estates was one-fifth of aggregate fixed investments in China by this time. By the end of 2011, inflation was quite prominent in the country, with the CPI index having risen by 5.1 per cent between January and December. ${ }^{19}$ Speculation, hovering on rising prices and possible turns in exchange rates generated the launch of Wealth Management Products (WMP) by banks. These were linked to speculation in stock markets, bonds, real estate and foreign exchange. ${ }^{20}$ Attempts by the state to control speculation included a strict ban by Wen Jiabao on the purchase of second and subsequent homes which in turn led to sharp declines in house prices as well as construction-related jobs by 2012 (Bradsher 2012).

Growth in China was noticeably lower by 2011-2012, with real growth touching a record low in recent months. This was related to factors which not only included

by 34 per cent (yoy) while cuts were announced in reserve ratios and sales of bonds were fewer (or non-existant), all in an effort to revamp the economy from its post-crisis slump (PBC, China Monetary Policy Report Quarter Three, 2009).

18. 'Dangers Looming in China's economy in 2010', Assia News.it 1-10-2010. 'Is China another real estate bubble?', Chris Isidore, April 15, 2010, at news.xinhuanet.com/english/ china/2012-01/17/c_122593675.htm.

19. 'Uncertainties cloud China's economy' at http//news.xinhuanet.com/englis/china/2012-0117/c_12.

20. Peterson Institute for International Economics, China Economic Watch at http://www.piie. com/blogs/china/. 
the slump in the export market overseas, but also domestic policies. With inflation continuing, the policymakers this time were facing a difficult choice, which was one of controlling inflation in an economy with stagnant growth performance. With commitments (though at an informal level) to manage the exchange rate and to continue with the free flow of capital from overseas, the outcome, as pointed out above, was one of an 'impossible trilemma', where monetary policy had to move in response to factors arising from external sources. The latter included a rise in liquidity available to the economy, caused by the changing flows of overseas capital and the level of reserves.

Views held by scholars differ as to whether China has retained autonomy in her monetary policy in the face of the obstacles underlying the policy debacles. In terms of one study (Reade and Volz 2011), the test should not rely only on whether short-term interest rates in China are driven by the Fed's monetary policy (that is, US interest rates). These authors argue that, by employing capital controls and relying on measures other than interest rates, China has been able to maintain 'relative autonomy' in monetary policy. As argued, the use of policy devices 'other than interest rates' (such as reserve ratios, the use of OMOs, etc.) are in essence also part of the package of monetary policy pursued by China. From this angle, interest rates have not always been the primary instrument of policy in the country. (Incidentally, the logic applies to countries like India as well, as I indicate later in this paper.)

However, there are views which oppose the above. I refer here to one more 'impossible trilemma' question, concerning the Asian economies (Patnaik and Shah 2010). While I do not share the prescriptions which follow in terms of using flexible exchange rates as a way out from the impasse in terms of the trilemma, I accept the views on situations of an 'impossible trilemma' in the high-growth Asian economies like China and India. Using measures of capital account openness by means of the Chinn-Ito database and also by gauging the extent of financial opening (or integration) by using Lane-Milessi-Ferretti calculations (which rely on ratios of stocks of financial assets plus liabilities to cumulative flows of GDP), the study arrives at a measure of de jure capital account opening for China and India during recent years. Such indicators, matched with exchange rates which are rather inflexible, have led these countries, as pointed out by the authors, to situations which can be described as an 'impossible trilemma'. As mentioned earlier, the twin surpluses in China's external accounts caused phenomenal increases in the country's official reserves. As a consequence, the economy witnessed steady expansions in liquidity.

Monetary management consists of a package which includes the different tools that can be used to influence the level of liquidity. The use of the interest rate is one of these, while others include cash-reserve ratios for banks and the sale of bonds (open market operations). It is noticeable that Chinese monetary authorities have been consistently making use of all three of the above, in a bid to contain the changing level of liquidity as well as the movements in the price index. Attempts on the part of monetary authorities to neutralise the upward pressures on RMB rates as well as the price rise in the domestic economy included direct purchases of foreign currency as well as sales of marketable bonds by the monetary authorities.

To arrive at a conclusive argument, I have correlated the monthly as well as the annual data for China for a few variables during the 5-year period between 2006 and 2010. The variables include official reserves, M2, RMB exchange rates vis-à-vis the US dollar, changes in price levels (CPI), sale of government bonds, bank rates and lending rates, and, finally, China's trade balance. 
Considering first the correlation results at 1 per cent level of significance, we observe the following:

1. Changes in reserves and in money supply are positively correlated, as is expected when policy changes in interest rates are guided by changes in money supply. The result holds for both the monthly and annual data for 2006-2010 (Tables 1 and $3 a)$.

2. Money supply and bond sales are positively correlated, as indicated by annual data for 1998-2010 (Table 2). Again, this is expected, and shows the use of monetary policy to ward off expansions in liquidity.

3 . Reserves and exchange rates of the RMB, however, have a negative relation during 2006-2010 (Table 3a). This can be interpreted by the management of the exchange rate in China which continued even after the de-link from the dollar in 2005.

Table 1 Correlation results for China: annual data from 2006-2007 to 2010-2011

\begin{tabular}{lcc}
\hline Variables & Reserves & Exchange rate \\
\hline Reserves & 1 & \\
Exchange rate & $(-) 0.9 * * *$ & 1 \\
Money supply & $0.98^{* *}$ & $(-) 0.8$ \\
\hline
\end{tabular}

Note: $* *$ and $* * *$ indicate statistical significance at 1,5 and 10 per cent level. The monthly figures are converted to annual and money supply is one-year lag. Source: Monthly Figure from People's Bank of China (PBC).

Table 2 Correlation results for China: annual data from 1998-99 to 2010-2011

\begin{tabular}{lccccc}
\hline Variables & Bank rate & Lending rate & CPI\% change & M2 & Bonds \\
\hline Bank rate & 1 & & & & \\
Lending rate & $0.55^{* *}$ & 1 & & & \\
CPI\% change & $(-) 0.16$ & 0.2 & 1 & & \\
M2 & $(-) 0.32$ & $(-) 0.06$ & $0.5^{* * *}$ & 1 & \\
Bonds & $(-) 0.29$ & $(-) 0.06$ & $0.60^{* *}$ & $0.98^{*}$ & 1 \\
\hline
\end{tabular}

Note: $*$, ** and *** indicate statistical significance at 1,5 and 10 per cent level.

Source: Annual figures from IFS.

Table 3 a Correlation results for China: monthly data from January 2006 to December 2010

\begin{tabular}{lccc}
\hline & Reserves & Exchange rate & Money supply \\
\hline Reserves & 1 & & \\
Exchange rate & $(-) 94^{*}$ & 1 & 1 \\
Money supply & $0.99 *$ & $(-) 0.89 *$ & 1 \\
\hline
\end{tabular}

Note: * indicates statistical significance at 1 per cent level of significance. The variables are used as monthly figures and money supply is one month lag. Source: Monthly figures from PBC. 
Table $3 b$ Correlation of trade with other variables in China during 2006-2010

\begin{tabular}{lcccc}
\hline & Money supply & Reserves & Balance of trade & Lending rate \\
\hline Money supply & 1 & & & \\
Reserves & $0.98^{*}$ & 1 & & \\
Balance of trade & $-0.91^{* * *}$ & $-0.9^{* * *}$ & 1 & 1 \\
Lending rate & -0.52 & -0.66 & 0.48 & 1
\end{tabular}

Note: $*$ and $* * *$ indicates statistical significance at 1 and 10 per cent level. The annual figures are used for the calculation of correlation coefficients.

Source: PBC.

Looking at the results at 5 per cent significance level, the following can be reported:

1. Sale of bonds and movements in prices (CPI) bear a positive relation between 1996 and 2010 (Table 2). This also shows a perceptible effort on the part of the monetary authorities to control prices by sales of bonds.

2. Money supply (M2) and reserves are positively correlated on the basis of annual data 1998-1999-2010 (Table 3a), a result which is also confirmed at the 1 per cent level for the same period (Table $3 b$ ) as reported above. The link confirms the impact of trade surpluses and net capital flows on money supply via changes in official reserves.

3. Lending rates and bank rates also move together, which is expected (Table 2).

The results given above indicate the distinct effect of China's external sector transactions on the package of monetary policies relating to the domestic economy. Accumulation of reserves, resulting from the trade and capital account surpluses which were enjoyed by the country, impacted the supply of money, which in turn prompted the use of sterilisation bonds (and also hikes in reserve ratios, especially during 2010 and 2011 when they were adjusted upwards several times) (Yongding 2011c). Incidentally, as pointed out previously, a large part of the post-crisis stimulus of the RMB 9.7 trillion during 2008 and 2009 was channelised via the banking system, responsible for additional bank credit amounting to RMB 7.3 trillion during the first half of 2009. Since such expansions were made possible under government pressure, it did not have to rely on the monetary base (including reserves). One also observes that the PBC stopped selling central government bills in the fourth quarter of 2008, which coincided with the onset of the global recession. Such steps led to expansions in liquidity in the market, pushing the interest rate in the inter-bank market below the deposit rates.

It can be observed that the expansionary policies of 2008 and 2009 moved in a reverse gear by 2010. As inflation was on the cards, monetary tightening set bank credit quota at RMB 7.5 trillion (as against RMB 9.7 trillion in 2009). As mentioned earlier, reserve requirements of the banks were raised several times during 2010-2011, open market operations used more effectively and inter-bank interest rates raised (Yongding 2009; 2011c).

Looking back, one notices the sharp swings in interest rates, with the lending rate ranging between 5.3 per cent and 12.6 per cent, and the bank rate between 2.7 per cent and 10.7 per cent, between 1990 and 2010 (see Figure 3). One can relate such swings initially to the changing scene of the Asian crisis, inducing steep cuts in interest rates between 1997 and 1999, followed by the upward movements from 2005 as capital inflows started peaking up and once again, with cuts in interest rates to combat the contractionary forces during the recent global downturn of 2007-2008. The latter 


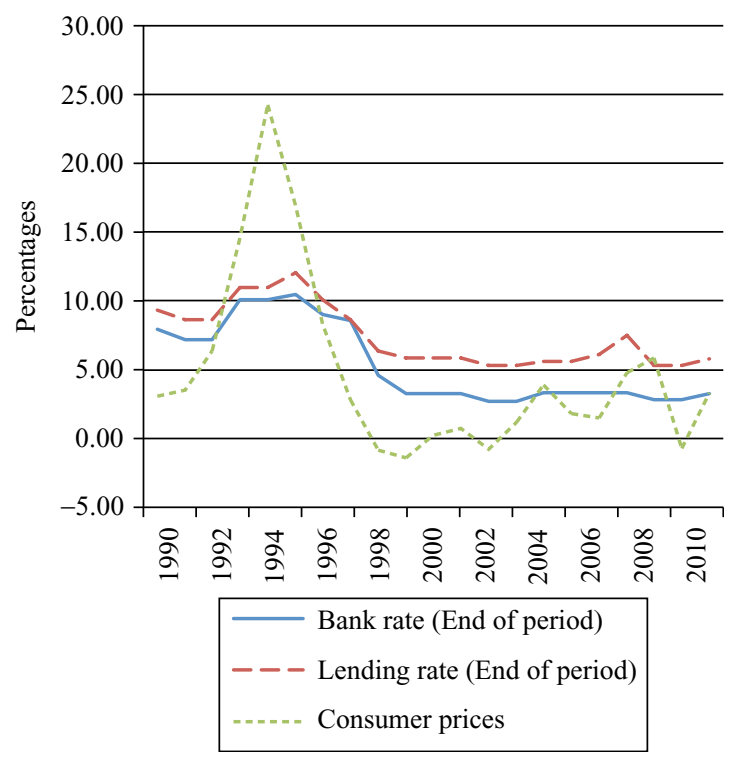

Source: IMF, International Financial Statistics.

Figure 3 China: bank rates, lending rates and CPI changes

was followed by a renewed tightening of rates over 2009-2010. Since 2005, the steady pace of liberal capital flows has led to expansions in portfolio inflows as well as stock market capitalisation (Sen 2007).

Such evidence helps us to conclude that free flows, as well as the volatility of overseas capital, had a significant impact on China's monetary and related policies; curbing, in the process, monetary autonomy in the economy.

\subsection{India}

With near-full convertibility of the Indian rupee and nearly free capital flows, official reserves held by India have been rising steadily, peaking by August 2011 to a level of $\$ 321$ billion which, after China, has been the highest held by the emerging market economies. The stock dipped marginally to $\$ 289.7$ billion by June $2012 .{ }^{21}$ Using the framework narrated above, I draw attention to the related changes within the economy, including the limits to options open to the policymakers.

Successive liberalisation of global capital flows to India since 1992-1993 has led to consistent increases in inflows of FDI and especially, of portfolio capital to the country. As a result, the capital account surpluses continued to be much in excess of the current account deficit experienced by the country. However, official interventions in the forex market transferred a considerable part of the currency inflows to the exchequer, thus contributing to expansions in the level of official reserves, while avoiding appreciations of the rupee rate. As already pointed out, additions to reserves (high-powered money) are capable of contributing monetary expansions, in turn posing additional problems for policymakers.

21. Reserve Bank of India, Handbook of Statistics on Indian Economy, 2012. 

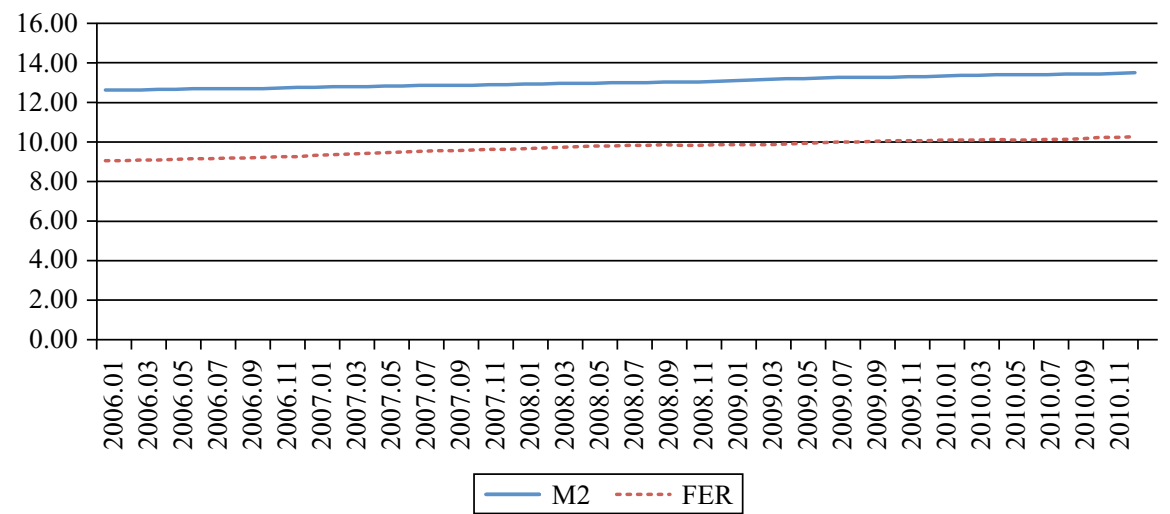

Source: Economic Survey, Government of India.

\section{Figure 4 India: $M 2$ and foreign exchange reserves (log values)}

I have observed in an earlier paper that monetary policy in India has often been conditioned by the exigencies related to the external sector; and, in particular, to the direct and indirect repercussions of the surges in capital flows (Sen 2010). Faced with expansions in money supply, which more than tripled from around Rs 20016 billion in 2003-2004 to nearly Rs 73592 billion by 2011-2012, ${ }^{22}$ and with inflationary pressures, especially on food items, authorities have been trying monetary sterilisation by selling government bonds, and trying other measures like raising the Cash Reserve Ratios (CRR), etc. Incidentally, sales of government bonds were also in conformity with the marketised borrowing programme of the government, which, in terms of the statutory norms of the Fiscal Responsibility and Budget Management Act (FRBMA) of 2003, substituted the responsibilities of non-market borrowings of the government from the central bank (as earlier practised under deficit finance) to the fiscal authorities. Market borrowings helped in controlling the fiscal deficit as a proportion of the GDP, thus complying with the terms of the statutory requirements (see Tables 6 and 7).

Attempts were also made by the monetary authorities in India to tighten/cheapen credit, by using hikes/reductions in interest rates, changes in repo as well as the reverse repo rates, and with variations in CRR maintained by banks with the RBI. ${ }^{23}$

To verify the arguments as above, I have used in the following pages the statistics relating to $\mathrm{M} 3$, exchange rate of rupee (ER), market borrowings of central and state governments (MBCS), FDI, portfolio flows, reserves, gross fiscal deficit (GFD), gross primary deficit (GPD) and some items in the budget under heads of expenditures, for the years 1990-1991 and 2010-2011 (see Figures 4 and 5a).

Tables 4 and 5 offer the correlation coefficients between annual values relating to selected variables as above during 1990-1991 and 2010-2011. The results indicate positive correlations at 1 per cent level of significance among levels as well as log values for the majority of calculations. The logic, as explained earlier in the context of China, relates to a sequence which runs from the rising capital inflows (FDI and portfolio) to a rise in reserves and related expansions in money supply which were

22. Reserve Bank of India, Handbook of Statistics on Indian Economy, 2011-2012 at http:// rbi.org.in/scripts/AnnualPublications.aspx.

23. As footnote 21 . 


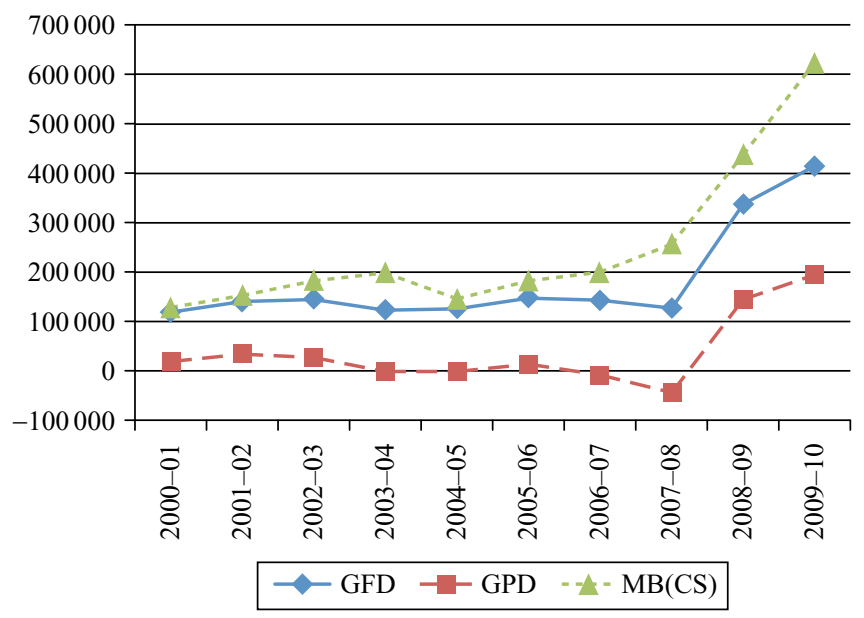

Note: GFD: Gross Fiscal Deficit; GPD: Gross Primary Deficit; MB(CS): Market Borrowing (of Central and State governments).

Source: Budget documents of the government of India.

Figure 5a India: fiscal deficit, primary deficit and market borrowings (in Rs crore)

Table 4 Correlation results for India from 1990-1991 to 2010-2011 at level form

\begin{tabular}{lllllllll}
\hline Variables & M3 & ER & GFD & GPD & MBCS & FDI & Portfolio & Reserves \\
\hline M3 & 1 & & & & & & & \\
ER & $0.96^{*}$ & 1 & & & & & & \\
GFD & $0.90^{*}$ & $0.76^{*}$ & 1 & & & & & \\
GPF & $0.57^{*}$ & 0.35 & $0.84^{*}$ & 1 & & & & \\
MBCS & $0.96^{*}$ & $0.85^{*}$ & $0.98^{*}$ & $0.5^{*}$ & 1 & & & \\
FDI & $0.96^{*}$ & $0.93^{*}$ & $0.85^{*}$ & $0.58^{*}$ & $0.90^{*}$ & 1 & & \\
Portfolio & $0.52^{* *}$ & $0.55^{* *}$ & 0.35 & 0.11 & $0.50^{* *}$ & $0.45^{* *}$ & 1 & \\
Reserves & $0.96^{*}$ & $1.00^{*}$ & $0.76^{*}$ & 0.35 & $0.85^{*}$ & $0.93^{*}$ & $0.55^{* *}$ & 1 \\
\hline
\end{tabular}

Note: $*, * *$ and $* * *$ indicates the statistical significance at 1,5 and 10 per cent respectively. M3: Broad Money; ER: Exchange Rates; GFD: Gross Fiscal Deficit; MBCS: Market Borrowing of Centre and State; FDI: Foreign Direct Investment; Portfolio: Portfolio foreign investment.

Source: Annual data from budget documents of the government of India.

sought to be neutralised with bond sales (and, as can be observed in Table 6a, by a rise in interest rates). The pattern is clearly indicative of limited autonomy in India's monetary policy over the years of capital account liberalisation during the last 2 decades.

With GDP growth rates tapering off to lower levels in recent years, the outcome signifies a trade-off between achieving what is considered as 'financial stability' and the developmental goals which include social sector spending. The dominance of finance in policymaking is clearly visible in these measures, following the dictates of global finance with compulsions which make for a selection of policies which are not necessarily conducive to the interests of the real economy. The pattern as above is also reflected in the relative drop in primary deficit as compared to the fiscal deficit in 
36 Review of Keynesian Economics, Vol. 2 No. 1

Table 5 Correlation results for India from 1990-1991 to 2010-2011 at log form

\begin{tabular}{lllllllll}
\hline Variables & M3 & ER & GFD & GPD & MBCS & FDI & Portfolio & Reserves \\
\hline M3 & 1 & & & & & & & \\
ER & $0.98^{*}$ & 1 & & & & & \\
GFD & $0.94 *$ & $0.89 *$ & 1 & & & & \\
GPF & $0.70 *$ & $0.62 *$ & $0.81 *$ & 1 & & & \\
MBCS & $0.97 *$ & $0.94 *$ & $0.96 *$ & $0.70 *$ & 1 & & \\
FDI & $0.95^{*}$ & $0.95 *$ & $0.90^{*}$ & $0.74 *$ & $0.94 *$ & 1 & & \\
Portfolio & $0.75^{*}$ & $0.80^{*}$ & $0.73 *$ & $50 * * *$ & $0.83 *$ & $0.84 *$ & 1 & \\
Reserves & $0.98^{*}$ & $1.00^{*}$ & $0.89 *$ & $0.62 *$ & $0.96 *$ & $0.95 *$ & 0.8 & 1 \\
\hline
\end{tabular}

Note: $*, * *$ and $* * *$ indicates the statistical significance at 1, 5 and 10 per cent respectively. Broad Money, ER: Exchange Rates; GFD: Gross Fiscal Deficit; MBCS: Market Borrowing of Centre and State; FDI: Foreign Direct Investment; Portfolio: Portfolio foreign investment.

Source: Annual data from budget documents of the government of India.

Table 6a Regression results using quarterly data 2000 Q1 to 2010 Q4

\begin{tabular}{llcc}
\hline Explanatory variables & Interest rate & Bond sales & Inflation rate \\
\hline Constant & $9.4(9.88)^{*}$ & $32.43(1.14)$ & $80.42(3.04)^{*}$ \\
GDP growth & & & $9.35(5.58)^{*}$ \\
Growth of M3 & $0.11(1.96)^{* *}$ & $0.23(0.16)$ & $2.11(1.45)$ \\
Bond sales & & & $0.22(1.75)^{*}$ \\
Inflation rate & & $-3.86(-2.88)^{*}$ & \\
$\mathrm{R}^{2}$ & 0.09 & 0.14 & 0.46 \\
F statistics & $3.84^{* *}$ & $4.29 * *$ & $14.64 *$
\end{tabular}

Note: $*$ and $* *$ indicate the level of statistical significance at 1 and 5 per cent respectively. The number of observations included is 56. The frequency of data is quarterly.

Source: Annual data from budget documents of the government of India.

\section{Table $6 b$ Regression equation M3 and interest rate}

\begin{tabular}{lcccc}
\hline Interest Rate $=15.2$ & -0.000001 Money $(\mathrm{M} 3)$ & & \\
\hline Predictor & Coef & SE Coef & $\mathrm{T}$ & $\mathrm{P}$ \\
\hline Constant & 15.1921 & 0.3005 & 50.55 & 0.000 \\
Money(M3) & -0.00000109 & 0.00000012 & -9.21 & 0.000 \\
$\mathrm{~S}=1.787$ & \multicolumn{2}{c}{$\mathrm{R}-\mathrm{Sq}=52.1 \%$} & $\mathrm{R}-\mathrm{Sq}(\mathrm{adj})=51.5 \%$ \\
\hline
\end{tabular}

Source: Annual data from budget documents of the government of India.

Table 7 Central and state governments deficit (in \% of GDP)

\begin{tabular}{lccr}
\hline & $2007-2008$ & 2008-2009 BE & 2009-2010 BE \\
\hline Revenue deficit & 0.2 & 4.4 & 5.5 \\
Gross fiscal deficit & 4.2 & 8.9 & 10.2 \\
Gross primary deficit & -1.3 & 3.5 & 4.6 \\
\hline
\end{tabular}

Note: BE: Budgetary Estimates.

Sources: RBI various issue and http://www.adbi.org/files/2010.09.17.wp249.fpiiag.tab.4.1.pdf. 
India, largely with steep increases in interest payments on government bonds as were sold to the public over the last few years.

When compared to China, India lacks the flexibility enjoyed by the former in managing finance using fiscal resources, given the statutory norms of fiscal compression. China has access to banks for countercyclical measures, while in India the related effects on volatility in the money and capital market, and on the measures of stop-go policies, are followed by monetary authorities (by injecting liquidity and restraining the latter as and when needed), using standard tools like reserve ratios, bank rates and open market operations in security market, have all been significant. On top of this, the open market operations have increased budgetary liabilities under the heading of interest payments, which have made it difficult to meet liabilities under other headings, such as social sector spending.

Using quarterly data between 2000 and 2010, I tried to test further the causal links between changes in variables, by using regression results with significance at 5 per cent level (Table 6a). The results explain changes in interest rates as a positive function of M3 growth, and also the inflation rate as a positive function of changes in GDP. Evidently, interest rates set by the monetary authorities during this period were a policy response to the supply of money, which, as mentioned earlier, followed changes in official reserves and capital flows. However, the results indicate a negative causal relation between the same variables, as we regress the data set for a longer period between 1991 and 2010 (Table 6b). The explanation rests on the standard inverse links between the interest rate and money supply in a market-determined system, when a rise in money supply exercises a dampening effect on interest rates. In contrast, the earlier case is one where the causal links run from monetary policy to interest rate, with monetary policy taking the lead to fix the interest rate in response to changes in money supply, as has happened in India since 2000.

A pattern such as in the first situation clearly indicates a loss of monetary autonomy on the part of policymakers, with policy changes which may be contrary to the interests of the real economy. As an example, one can mention the tightening of credit by the Reserve Bank of India, the central bank which has been introducing upward rounds of movements in interest rates since 2011-2012, along with hikes in cash-reserve ratios and open market sales of government bonds, all in a bid to mop up liquidity in the market. Thus the repo rate (which is the rate at which money is injected into the system by the central bank) was adjusted five times between May and October of 2011, rising from 7.25 per cent in May to 8.50 per cent in October. ${ }^{24}$ A minor relaxation in the cash reserve ratio by 25 basis points in terms of the last quarterly monetary policy announcement of October 2012 expects to release liquidity worth Rs 175 billion into the economy. However, the prime rate fixed by the Bank along with the repo rate was kept unchanged, despite pressures from the Ministry of Finance to accommodate the growth target. ${ }^{25}$ Continuing with the steep increases in interest rates, which was initiated in 2011-12, the move has been clearly opposed to the interests of the real economy which at the moment is urgent need for revival. The latter is evident in the recent drop in GDP, from an average of 8.4\% over 2009-2011 to 6.1\% during the quarter ending December 2011. ${ }^{26}$

The monetary policy package of the government in India in response to the external sector related changes included, as mentioned above, open market policy with sales of government bonds. From an average of Rs 734 billion in 2000-2001, the net market

24. Reserve Bank of India Bulletin, December 2010.

25. As footnote 23 .

26. www.ndtv.com. 


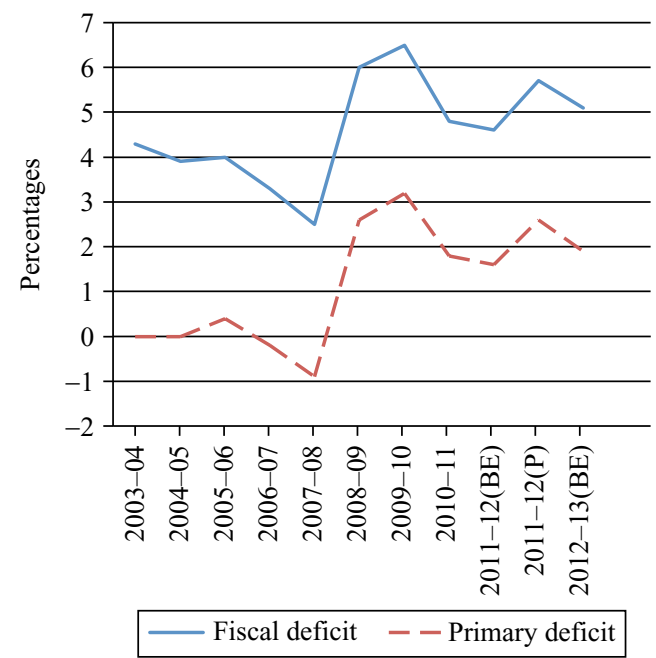

Notes: BE: Budget Estimates; P: Provisional Accounts.

Source: Government of India, Economic Survey, 2012-2013, p. 57.

\section{Figure 5b India: budget deficits as percentages of GDP}

borrowings of the government rose to Rs 4843 billion and Rs 4930 billion respectively in 2011-2012 and 2012-2013. ${ }^{27}$ These measures of market borrowings were obviously connected to the overall limit in terms of the FRBMA on the fiscal deficit.

However, it is notable that market borrowings were also prompted by the rising M3, and here I draw attention to the positive correlation between M3 and market borrowings shown in Tables 4 and 5 (where the correlation is significant). This can be observed from my tests with sales of bonds regressed on changes in M3 as well as the inflation rate (see Table 6a).

However, unlike what is usually postulated in mainstream policies, growth rates in M3 do not bear any significant relation to price changes in terms of the same tests (Table 6a). The result clearly dampens the quantity-theoretic arguments underlying the policies of inflation targeting. Prices, as can be argued, can always be influenced by factors (say supply of output) other than sheer money supply.

On the whole, the exercise reported above confirms the argument put forward earlier that monetary policy in India has been subject to the exigencies arising out of the open capital account and the need to manage the real exchange rate of the rupee at a competitive level along with the goal to control inflation.

Let us now analyse some further implications of the monetary policy package, and, in particular, of monetary sterilisation by means of bond sales. The latter, sold to the public, go with interest payments in the budget and add to expenditure in the fiscal budget, which, again, is subject to the restraints of the FRBMA limiting the size of the deficit. As the interest bill goes up, the fiscal deficit less interest payments (or the primary deficit) over years has further reduced as a proportion of GDP (see Figure 5b). Looking at the other expenditure headings in the primary budget, including subsidies, capital

27. RBI, Handbook of Statistics of Indian Economy, at http://rbi.org.in/scripts/PublicationsView. aspx?id=14458. 


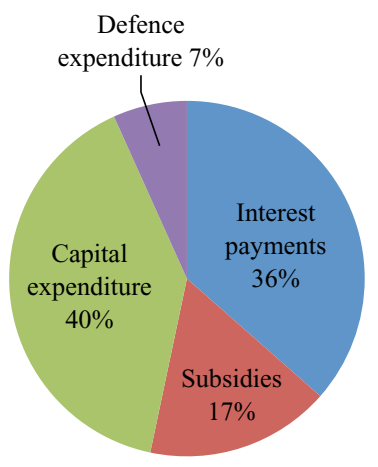

Figure 6 India: budgetary expenditure, 1991-1992

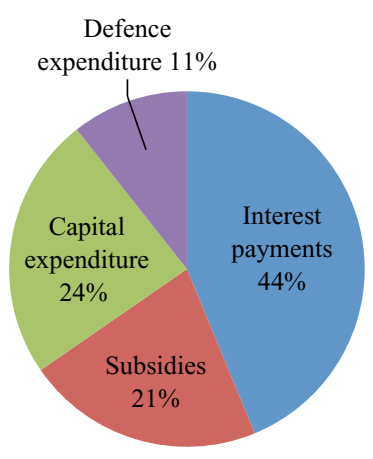

Figure 7a India: budgetary expenditure, 2009-2010

expenditures and defence expenditures, a major brunt of the cut in the primary deficit seems to have fallen on capital expenditure (see Figures 5b, 6, 7a, 7b and 9, and Tables 7 and 8). At the same time, the interest payments bill has been rising, both as a share of budgetary expenditure and in absolute terms (see Figures 6, 7a, 7b and 8).

The pattern described above for India can be summed up as follows:

1. there have been sharper declines in primary deficit as compared to the fiscal deficit, which have been caused by interest payments on government bonds sold to the public over the last few years;

2. market borrowings in recent years have gone up; and

3 . the composition of expenditure in the primary budget ${ }^{28}$ has changed, with interest payments far exceeding the payments under the headings of subsidies and capital expenditures.

28. In terms of budget classification in India, Fiscal Deficit $=$ Total Expenditure - Total Receipts $=($ Revenue Expenditure + Capital Expenditure $)-$ Total Receipts; or, Fiscal Deficit $=$ (Interest Payments + Subsidies + Defence Expenditure + Capital Expenditure) - Total Receipts; or Primary Deficit $=$ Fiscal Deficit - Interest Payments $=($ Subsidies + Defence Expenditure + Capital Expenditure) - Total Receipts. 
40 Review of Keynesian Economics, Vol. 2 No. 1

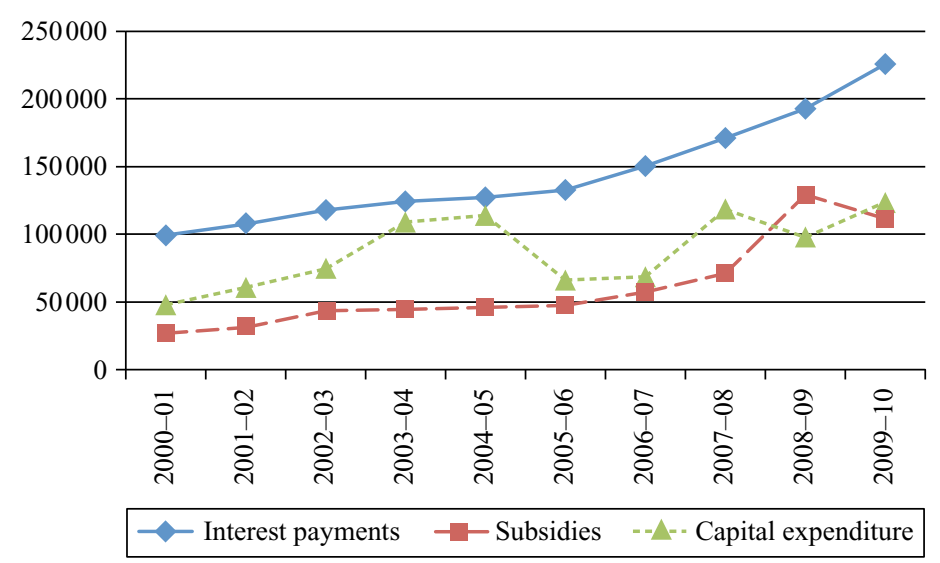

Source: Budget documents of the government of India.

Figure $7 b$ India: major expenditure headings of central government (in Rs crore) subsidy to GDP

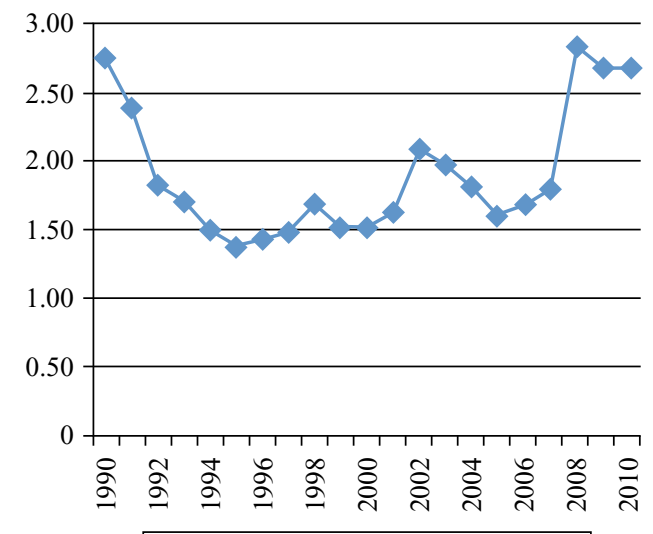

Subsidy as a percentage of GDP

Source: Economic Survey of India, cited in Dasgupta (2012).

\section{Figure 8 India: subsidies as a percentage of GDP}

An outcome as described above in relation to India signifies a trade-off, between achieving what is considered as 'financial stability' (inflation targeting, exchange rate management) and developmental goals (which include the pitching of a growthinducing interest rate and commensurate levels of social-sector spending). Dominance of finance is clearly visible in these measures of policymaking in developing economies, with compulsions which make for a selection of policies that are not necessarily conducive to the interests of the real economy.

The trilemma (or quadrilemma) which India has been facing with the closer integration with global financial markets has thus not only impaired the monetary policies that have been consistently sidelining the interests of real growth but has also changed 


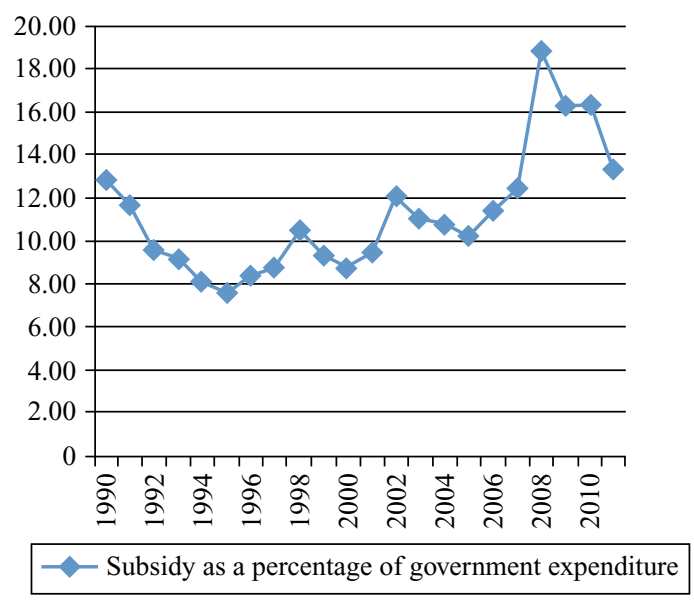

Source: Economic Survey of India, cited in Dasgupta (2012).

Figure 9 India: subsidy as a percentage of government expenditure

Table 8 Major headings of expenditure: central and state governments (in Rs crore)

\begin{tabular}{lcrrr}
\hline Years & Interest payments & Subsidies & Capital expenditure & $\begin{array}{c}\text { Capital defence } \\
\text { expenditure }\end{array}$ \\
\hline $1991-1992$ & 26596 & 12253 & 29122 & 4905 \\
$1992-1993$ & 31075 & 10824 & 29916 & 5473 \\
$1993-1994$ & 36741 & 11605 & 33684 & 6867 \\
$1994-1995$ & 44060 & 11854 & 38627 & 6819 \\
$1995-1996$ & 50045 & 12666 & 38414 & 8015 \\
$1996-1997$ & 59478 & 15499 & 42074 & 8508 \\
$1997-1998$ & 65637 & 18540 & 51718 & 9104 \\
$1998-1999$ & 77882 & 23593 & 62878 & 10036 \\
$1999-2000$ & 90249 & 24487 & 48975 & 11855 \\
$2000-2001$ & 99314 & 26838 & 47753 & 12384 \\
$2001-2002$ & 107460 & 31210 & 60842 & 16207 \\
$2002-2003$ & 117804 & 43533 & 74535 & 14953 \\
$2003-2004$ & 124088 & 44323 & 109129 & 16863 \\
$2004-2005$ & 126934 & 45957 & 113923 & 31994 \\
$2005-2006$ & 132630 & 47522 & 66362 & 32338 \\
$2006-2007$ & 150272 & 57125 & 68778 & 33828 \\
$2007-2008$ & 171030 & 70926 & 118238 & 37462 \\
$2008-2009$ & 192694 & 129243 & 97507 & 41000 \\
$2009-2010$ & 225511 & 111276 & 123606 & 54824 \\
\hline
\end{tabular}

Source: Budget documents of the government of India.

the composition of public expenditure, away from distributional justice to the rentier interests. Examples are not difficult to find, with the RBI's use of inflationary targeting in recent times (which include tightening of credit by successive rounds of hikes in primary lending rates and reserve ratios), which has been continuing despite the low growth performance of the economy, especially in the industrial sector. 
42 Review of Keynesian Economics, Vol. 2 No. 1

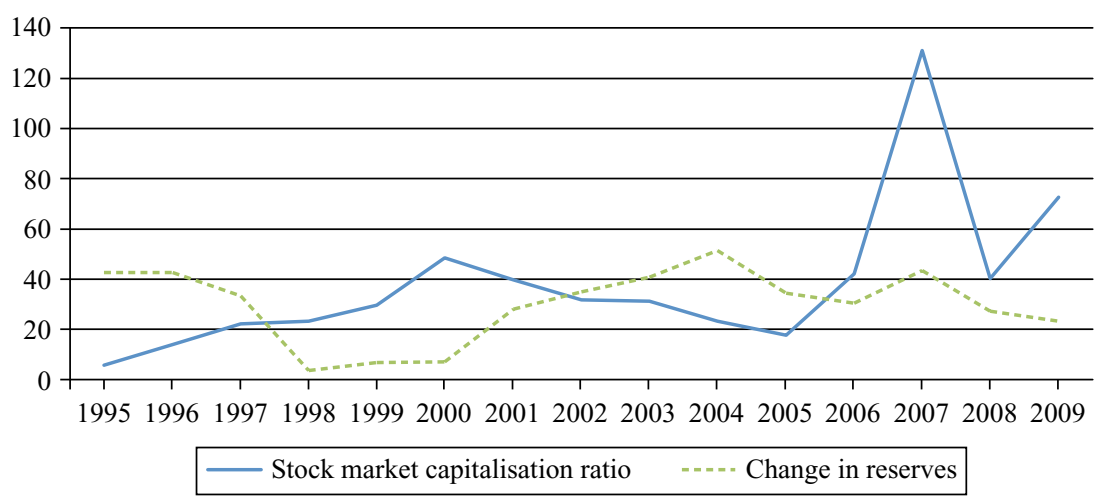

Source: Government of India, Economic Survey.

Figure 10 India: stock market capitalisation and change in official reserves (in per cent)

\section{CONCLUDING NOTES}

The narrative as well as the analysis of the global inbalance that exist in the literature tend to remain incomplete unless they capture the story relating to the experiences of the emerging economies which have faced surges in capital flows. While ignoring the implications of capital flows on the domestic economies of those countries, especially in terms of the 'impossibility' of following a monetary policy that is conducive to growth in their respective economies, such analysis also fails to recognise the significance of uncertainty and changes in expectations in the process. The above operate as factors behind the build up of the large official reserves, often in a precautionary mode. The consequences, however, are multi-faceted in these economies.

The experiences of China as well as those of India, with their deregulated financial sectors, bear testimony to the points mentioned above. China at least had the capacity to make use of the fiscal budget to amend the unwanted consequences. However it has already experienced the volatile and short-term capital flows which set the direction of investments to spheres of short-term profitability. Furthermore, the high level of reserves, with a large portion invested in the US, creates the significance of the US for China, not only as a major trade destination but also in terms of the dollar value of wealth invested in the US.

As for India, the country lacks the flexibility enjoyed by China in managing finance by using fiscal resources, especially within the norms of fiscal compression. The related effects of financial integration include volatility in the money and capital market, the related actions by monetary authorities, both in injecting liquidity as needed and more often in restraining the latter by using standard tools like reserve ratios, bank rates and open market operations in the security market. The latter has already increased the budgetary liabilities under the heading of interest payments, which makes it difficult to meet liabilities under other headings such as social-sector spending.

Financial integration and free capital mobility, which are supposed to generate growth with stability in terms of the 'efficient market' hypothesis, has not only failed to achieve its promises, especially in the advanced economies, but has also pushed the high-growth developing economies like India and China to a state of compliance, where domestic goals of stability and development are sacrificed to attain the globally sanctioned norms of free capital flows. 


\section{REFERENCES}

Aizenman, Joshua (2010), 'The Impossible Trinity (aka The Policy Trilemma)', in Jerry Capiro (ed.), The Encyclopedia of Financial Globalization, Oxford: Elsevier.

Bernanke, Ben (2005), 'The Global Saving Glut and the U.S. Current Account Deficit', March 10, at http://www.federalreserve.gov/boarddocs/speeches/2005/200503102/.

Black, Aaron (2012), 'China PBoC Newspaper urges Open Capital Account', at www/marketwatch.com/story.china.

Bottelier, Pieter (2009), 'China and the Financial Crisis', in Ashley J. Tellis, Andrew Marble and Travis Tanner, The National Bureau of Asian Research, at http://www.carnegieendowment. org/2009/10/14/china-and-international-financial-crisis/2hl.

Bottelier, Pieter (2011), 'Emerging Market Economies, Global Trade Imbalances, and the US Dollar: An Interview with Pieter Bottelier', NBER, April 25, at www.nber.org.

Bradsher, Keith (2012), 'China Confronts Mounting Piles of Unsold Goods', at http://economywatch. $\mathrm{com} /$ worldeconomy/china.

Dasgupta, B. (2012), 'Subsidies Unlikely to be Reduced', Business Economics (e-journal), March 1-15.

Dunaway, Stephen (2009), Global Imbalances and the Financial Crisis, Council on Foreign Relations, March, at http://www.cfr.org/economics/global-imbalances-financial-crisis/p18690.

Ehnts, Dirk H. and Finn M. Korner (2011), 'The True Costs of Sterilization: What it Takes to Manage China's Exchange Rate', mimeo, October 27.

Green, Stephen (2003), 'China's Stock Market: Eight Myths and Some Reasons to be Optimistic. A Report from the China Project', The Royal Institute of International Affairs Asia Programme, February.

Herr, Hansjörg, Torsten Niechoj, Claus Thomasberger, Achim Truger and Till van Treeck (eds) (2012), From Crisis to Growth? The Challenge of Debt and Imbalances, Marburg: MetropolisVerlag.

IMF (2013), Principal Global Indicators, at http://www.principalglobalindicators.org/default. aspx.

Krugman, P. (1999), 'O Canada: A Neglected Nation Gets its Nobel', Slate Magazine, posted October 19.

McKinnon, Ronald (2010), 'A Stable Yuan-Dollar Rate Forever?', East Asia Forum, March 17.

Palley, Thomas (2009), 'Rethinking the Economics of Capital Mobility and Capital Controls', PERI Working Paper 193, February.

Patnaik, Ila and Ajay Shah (2010), 'Asia Confronts the Impossible Trinity', National Institute of Public Finance and Policy Working Paper, January.

Peng, Wensheng, Hui Miao and Nathan Chow (2007), 'Price Convergence between Dual-Listed A and H shares', China Economic Issues, 6/07, November, at www.info.gov.hk/hkma/eng/ research/cei/2007/CEI-200706.pdf.

Reade, J. James and Ulrich Volz (2011), 'Chinese Monetary Policy and Dollar Peg', at www. twnmacro.org/TW2011/papers/Volz.pdf.

Sen, Sunanda (2007), 'China in the Bull Shop: Dealing with Finance after WTO', in A.K. Bagchi and Gary Dymski (eds), Capture and Exclude, Delhi: Tulika. (Earlier versions were: 'China's Finance after WTO', Economic and Political Weekly, 2007; and 'Finance in China', China Model or Beijing Consensus for Development, Beijing: Social Science Academic Press, 2006 [in Chinese].)

Sen, Sunanda (2010), 'Managing Finance in Emerging Economies', Levy Institute of Economics Working Paper No 630, December. (Also in: Alternative Economic Survey, Delhi: DK Agencies, 2010).

Subramonian, Arvind (2010), 'China Key to Unwinding the Global Imbalances', Economic Times, April 20.

Treasury Direct (2012), at http://www.treasury.gov/resource-center/data-chart-center/tic/Documents/ mfh.txt.

Yongding, Yu (2009), 'China's Policy Response to Global Financial Crisis', Richard Snape Lecture, November 25, Australian Productivity Council, Melbourne (mimeo). 
44 Review of Keynesian Economics, Vol. 2 No. 1

Yong, Wang (2010), 'Avoiding a US-China Currency War: Need for Rational Calculation', Peking University, April 11.

Yongding, Yu (2011a), 'China Must Avoid Lending to Troubled Euro-Asia Nations', at www. BloombergNews, September 11.

Yongding, Yu (2011b), 'The Chinese Bear's Feeble Growl', at www.project-syndicate.org, November 29.

Yongding, Yu (2011c), ‘China's Macro-economic Situation and Some Policy Issues', June 22, Paris (mimeo).

Yongding, Yu (2012), 'Witness to Final Imbalances: A Double Surplus, the Yuan Exchange Rate and the Dollar Trap', at www.English.caixin.com. 